\title{
Assessment of changes in blood lactate levels in children and adolescents with type 1 diabetes during a football tournament (GoalDiab Study)
}

Ocena zmiany stężenia mleczanów u dzieci i młodzieży z cukrzycą typu 1 podczas turnieju piłki nożnej (GoalDiab Study)

\author{
'Justyna Flotyńska*, ${ }^{1}$ Andrzej Gawrecki*, ${ }^{1}$ Aleksandra Araszkiewicz, ${ }^{1}$ Mikołaj Parchimowicz, \\ ${ }^{1}$ Marcin Michalski, ${ }^{1}$ Olga Różańska, ${ }^{1}$ Marta Stopczyńska-Szymecka, ${ }^{1}$ Mikołaj Kamiński, \\ ${ }^{1}$ Aleksandra Cieluch, ${ }^{2}$ Grzegorz Biegański, ${ }^{3,4}$ Arkadiusz Michalak, ${ }^{5}$ Katarzyna Domaszewska, \\ ${ }^{1}$ Dorota Zozulińska-Ziółkiewicz
}

\author{
*equal contribution \\ ${ }^{1}$ Department of Internal Medicine and Diabetology, Poznan University of Medical Sciences, Poland \\ ${ }^{2}$ Department of Infectious Diseases and Paediatric Neurology, Poznan University of Medical Sciences, Poland \\ ${ }^{3}$ Department of Paediatrics, Diabetology and Endocrinology, and Nephrology, Medical University of Lodz \\ ${ }^{4}$ Department of Biostatistics and Translational Medicine, Medical University of Lodz \\ ${ }^{5}$ Department of Physiology and Biochemistry, Poznan University of Physical Education
}

\begin{abstract}
Introduction: Monitoring physical activity is a very important issue, especially in type 1 diabetes. One of the parameters assessing the intensity of exercise is the concentration of lactate in the blood.

Aim of the study: We assessed the intensity of PE and changes in lactate levels in children and adolescents with type 1 diabetes (T1D) during a football tournament.

Material and methods: We enrolled 141 participants, the results of 70 of whom were analyzed, playing in two age categories: 10-13 and 14-17 years. Lactate levels were measured in the capillary blood before and after matches. Blood lactate of $4 \mathrm{mmol} / \mathrm{l}$ (Onset Blood Lactate Accumulation OBLA) was used as parameter indicating the prevalence of anaerobic metabolic changes.

Results: The median lactate level was $1.8 \mathrm{mmol} / \mathrm{l}$ before and $4.4 \mathrm{mmol} / \mathrm{l}$ after matches $(p<0.001)$. The increase in lactate levels was higher in the older age category $(4.3$ vs. $1.8, p=0.001)$ and was independent on gender (3.2 vs. 2.1, $p=0.597)$, personal insulin pump vs insulin pen use (3.0 vs. $1.5, p=0.145)$ or training in a sports club (1.4 vs. 3.0, $p=0.084)$. A positive correlation was noted between increased lactate levels and age $(R s=0.253, p=0.034) .61 \%$ of the participants exceeded lactate levels $\geq 4 \mathrm{mmol} / \mathrm{l}$. In univariate logistic regression analysis age was a significantly associated with lactate level $\geq 4 \mathrm{mmol} / \mathrm{I}[\mathrm{OR}=1.45(1.08-1.95)]$ independent of $\mathrm{HbA}_{1 c^{\prime}}$ gender, treatment method and training in a sports club.

Conclusions: PE intensity levels during football matches were found to be mixed aerobic-anaerobic. Increases in lactate levels were greater in the older subjects independently on the assessed factors.

Key words:

physical activity, lactate, type 1 diabetes, physical exercise intensity.

\section{Streszczenie}

Wstęp: Monitorowanie aktywności fizycznej jest bardzo ważne, szczególnie w cukrzycy typu 1. Jednym z parametrów oceniających intensywność aktywności jest stężenie mleczanu we krwi.

Cel pracy: Ocena intensywności wysiłku fizycznego i zmiany poziomu mleczanu we krwi u dzieci i młodzieży z cukrzycą typu 1 podczas turnieju piłkarskiego.

Materiał i metody: Do badania zakwalifikowano 141 osób, w analizach uwzględniono wyniki 70 zawodników, grających w dwóch kategoriach wiekowych: 10-13 oraz 14-17 lat. Stężenia mleczanu mierzono przed i po zakończeniu każdego meczu. Stężenie mleczanu 4 mmol// (OBLA) zostało użyte jako parametr wskazujący początek beztlenowych przemian metabolicznych.
\end{abstract}


Wyniki: Mediana stężeń mleczanu wynosiła przed 1,8 mmol/l i wzrosła do 4,4 mmol/l po meczach $(p<0,001)$. Przyrost mleczanów był wyższy u starszych dzieci $(4,3$ vs 1,8; $p=0,001)$, nie zależał od płci $(3,2$ vs 2,1, $p=0,597)$, stosowania osobistej pompy insulinowej lub penów insulinowych $(3,0$ vs $1,5, p=0,145)$ oraz trenowania w klubie sportowym $(1,4$ vs 3,0, $p=0,084)$. Odnotowano dodatnią korelację pomiędzy przyrostem stężenia mleczanu a wiekiem (Rs $=0,253, p=0,034$ ). 61\% zawodników podczas meczu przekroczyło intensywność wysiłku odpowiadającą własnemu obciążeniu progowemu czego efektem był poziom mleczanu ( $\geq 4 \mathrm{mmol} / \mathrm{l})$. W analizie regresji logistycznej udowodniliśmy, że wiek był istotnie związany ze stężeniem mleczanu $\geq 4 \mathrm{mmol} / \mathrm{l}$ $[\mathrm{OR}=1,45(1,08-1,95)])$. Związek ten jest niezależny od wartości HbA 1' $^{\prime}$ płci, metody leczenia i trenowania w klubie sportowym. Wnioski: Intensywność wysiłku fizycznego u nastolatków z cukrzycą typu 1 podczas meczów piłkarskich była mieszana - tlenowo-beztlenowa. Wzrost stężenia mleczanów po wysiłku fizycznym był wyższy u starszych uczestników oraz nie zależał od innych czynników.

\section{Słowa kluczowe:}

aktywność fizyczna, cukrzyca typu 1, mleczany, intensywność wysiłku fizycznego.

\section{Introduction}

Type 1 diabetes (T1D) is a chronic autoimmune disease. Dysfunction of the pancreatic beta cells is the cause of complete insulin deficiency [1]. The disease may present at any age, though onset mainly affects children, adolescents and young adults [2]. The most serious clinical issues relating to T1D are chronic complications such as retinopathy, neuropathy and diabetic kidney disease [3]. Scientific studies have found that intensive functional insulin therapy plays an essential role in the prevention and treatment of chronic complications [1, 4]. The phenomenon of "hyperglycaemic memory" proves that good blood glucose control is important from the very onset of diabetes [5]. Unfortunately, despite remarkable progress in the treatment and monitoring of diabetes, recent years have shown that people with T1D continue to have problems achieving their blood glucose targets [6] and experience lower quality of life than the healthy population [7].

One of the best tools in the treatment of T1D is physical activity, because it increases insulin sensitivity, improves glucose distribution and reduces daily insulin demand [8]. Moreover, systematic physical activity increases oxidative stress tolerance and improves immunity [9]. Physical activity is recommended by diabetology societies. Regular physical activity improves the cardiovascular risk profile, lipid profile and the body's musclefat ratio [10].

Three types of physical exercise can be distinguished: aerobic, anaerobic and mixed. The classification depends mainly on intensity and duration of physical activity [11]. Assessing the intensity of physical exercise is a very important factor in planning insulin therapy and is an element of diabetes patient education. Aerobic exercise is characterised by a moderate level of intensity and long duration; its most important sources of energy are glucose and fatty acids. In aerobic exercise, the heart rate remains below $65 \%$ of its maximum value $\left(\mathrm{HR}_{\max }\right)$ most of the time. In contrast, anaerobic exercise is characterised by high intensity and short duration as well as by its independence from exogenous oxygen delivery. The predominant sources of energy are anaerobic mechanisms of ATP resynthesis, mainly based on glycolysis [12]. Most people engaging in such exercise have heart rates above $75-90 \%$ of $\mathrm{HR}_{\max }$.

From the standpoint of physical exercise biochemistry, lactate is a very important metabolite, because its excess is released into the bloodstream and used for the production of energy by active muscles as well as the heart and brain [13]. The remaining portion serves as a substrate for glucose synthesis. Lactate is also involved in such complex processes as memory formation and neuroprotection. High-intensity exercise has been proven to retard brain ageing processes and to reduce the risk of neurodegenerative disorders. In addition to the loss of muscle glycogen, lactate accumulation in muscles and reduced muscle $\mathrm{pH}$ in the course of intense physical exercise also contribute to fatigue. However, the immediate cause of this state is potassium released from contracting muscles. Systematic physical activity leads to adaptive metabolic changes that increase aerobic capacity and muscle potential as well as reduce anaerobic metabolic processes during performance of exercises of the same intensity. From a metabolic standpoint, persons with a higher $\mathrm{VO}_{2 \max }$ (maximum rate of oxygen consumption) have a greater capacity to activate aerobic ATP resynthesis mechanisms in their active muscle fibres, yet are also able to metabolise lactate more quickly after finishing physical exercise [14].

Lactate measurements has been used for many years across all sports, and it is one of the most used metrics in the world of training by athletes and coaches worldwide. Lactate levels were measured during matches not only to assess exercise intensity and determine the origin of energy sources for ATP resynthesis, but also to assess individual players' metabolic reactions to specific match exertion loads. The results of tests measuring blood acidification of young football players during match exercise indicate their movements are acyclic, changing in rhythm and pace as the situation on the pitch requires. Moderate-intensity exertion alternates with very highintensity exercise. The observed movement forms are: starts from different positions and in variable directions, accelerations, repeated runs with and without the ball covering several tens of metres, dribbling, jogging and walking [15]. Research by Bangsbo found that during a match only ca. $2 \%$ of a player's energy is generated by anaerobic processes. These processes are very important for training purposes, because they enable a player to perform highly intensive exercise [16]. In healthy persons, the ability to achieve a high level of anaerobic exertion depends on age.

The First Polish Football Championship for Children and Adolescents with Type 1 Diabetes was held to promote 
a healthy lifestyle and physical activity as important elements of type 1 diabetes management [17]. During the tournament, a multidirectional assessment of participants' physical activity and its effects on metabolic changes in their blood serum was performed. The purpose of this part of the study was to determine blood serum lactate levels in the metabolic reaction to match exercise in children with type 1 diabetes.

\section{Aim of the study}

The objective of the study was to assess the intensity of physical exercise and lactate levels in children and adolescents with T1D during football matches in the course of a football tournament.

$\mathrm{H1}$ : During a football game, we should observe a mixed effort: aerobic-anaerobic.

$\mathrm{H} 2$ : Changes in blood lactate levels depend on anthropometric factors and the mode of insulin therapy.

\section{Material and methods}

The observational study covered a group of 189 players with T1D who came from 11 places scattered throughout Poland. The study was approved by the Bioethics Committee (No. 170/17). Players aged 10-13 years and 14-17 years $(n=141)$ were selected to participate in this part of the study focusing on changes in lactate levels. Younger children were not included in the study because they were considered to be incapable of fully cooperating with researchers to perform measurements of capillary blood lactate levels immediately after matches.

The criteria for inclusion in the study were: age below 18 years, type 1 diabetes diagnosed according to the criteria of ISPAD guidelines [18], intensive functional insulin therapy (by continuous subcutaneous insulin infusion through a pump or insulin pens injecting long-acting insulin 1 or 2 times per day or more frequent injections of rapid-acting insulin), consent of the treating physician, parental consent and, in the case of players over 16 years of age, their own assent. Criteria excluding participation in the study were: the presence of advanced chronic complications of diabetes (proliferative retinopathy, diabetic maculopathy, peripheral or autonomic neuropathy, stage III or IV diabetic kidney disease), diabetic ketoacidosis or severe hypoglycaemia within the last 30 days, identified cardiovascular, respiratory or musculoskeletal diseases, or psychiatric disorders. The inclusion and exclusion criteria were specified during registration for the tournament.

\section{Study protocol}

Information about diabetes duration and treatment method was obtained via application forms and questionnaires completed by parents and their children's diabetes specialists. Information regarding training in sports clubs was obtained via a separate form completed during the tournament. Detailed interviews and physical examinations were also performed, including blood pressure measurements.
The players were divided into three age categories: 7-9 years $(n=40), 10-13$ years $(n=81)$ and $14-17$ years $(n=68)$. These age categories were selected based on personality traits and adolescence and developmental periods. They correspond with the structure of compulsory schooling in Poland: 7-9 years - early primary school (grades 1-3), 10-13 years (grades 4-8, where lessons begin to be divided by subject) and 14-17 years (post-primary school) [19]. Twentythree teams participated in the tournament. Each team played 4-6 matches lasting 30 minutes apiece, on 3 football pitches: two measuring $50 \times 40 \mathrm{~m}$ and one measuring $56 \times 26 \mathrm{~m}$ (for the 14-17 age category). Three qualification matches were held on the first day, and semi-finals and finals were held on the second day. Every match was played in the presence of qualified medical staff consisting of a physician - diabetes specialist, a nurse and a medical student.

Glycated haemoglobin $\left(\mathrm{HbA}_{10}\right)$, blood glucose, lactates

Glycated haemoglobin levels in capillary blood samples were measured immediately before the start of the tournament using the D-10 Haemoglobin $A_{1 c}$ Program (Bio-Rad Laboratories, Hercules, CA, BioRad, Marnes-la-Coquette, France). Blood glucose levels were measured before and after each match by the medical team using glucose meters (Contour Plus One; Ascensia Diabetes Care). Capillary blood lactate levels were measured before and after each match using the Lactate Scout, EKF-Diagnostics (Manufacturer SensLab $\mathrm{GmbH}$, Leipzig, Germany). The analysis of exercise blood lactate concentration was used to divide the players into two groups. The cut-off point was lactate concentration $>4 \mathrm{mmol} / \mathrm{l}$ which corresponds to OBLA (Onset Blood Lactate Accumulation). OBLA, which indicates the significant predominance of anaerobic mechanisms in ATP resynthesis, is known as the threshold load, and the measurement of OBLA is one of the methods for determining when the threshold load has been reached.

\section{Statistical considerations}

All data are expressed as a median and interquartile range (IQR) or percent (\%) of the study subjects. Distribution normality was checked using the Lilliefors-corrected KolmogorovSmirnov test. Because the distribution was short of normality, non-parametric tests were used to assess the data collected. The statistical analysis was performed using the program STATISTICA 12.0. Inter-group differences were assessed using the Mann-Whitney test, $\chi^{2}$ or Fischer's exact test. Spearman's rank correlation coefficient was used to determine the correlation between lactate levels and study subject age. Differences with a probability value of $<0.05$ were considered statistically significant. The study compared lactate levels between two age groups (10-13 and 14-17 years). Lactate level differences between genders were also assessed, before and after matches, depending on diabetes treatment method (personal insulin pump or insulin pen) and membership in a sports club. Variables were divided and analysed in respect to exceedance of the blood lactate concentration $\geq 4 \mathrm{mmol} / \mathrm{l}$. 


\section{Results}

A football tournament involving 189 players with T1D was held. Ultimately 141 of them were enrolled in the study (in the second and third age categories). The analyses included re-

Table I. Characteristics of the study participants

\begin{tabular}{ll}
\hline Parameters & $n=70$ \\
\hline Gender, $n(\%)$ & $63(90)$ \\
\hline Boys & $7(10)$ \\
\hline Girls & $12(1113)$ \\
\hline Age, years & $7.3(7.08 .2)$ \\
\hline$A_{10}, \%$ & $9(13)$ \\
\hline Diabetes treatment method, $n(\%)$ & $61(87)$ \\
\hline Pens & $20(29)$ \\
\hline Training in sports clubs, $n(\%)$ & $50(71)$ \\
\hline Club player & $1.8(1.5-2.5)$ \\
\hline Amateur & $4.4(3.1-6.7)$ \\
\hline Lactate before the game, $\mathrm{mmol} / \mathrm{l}$ &
\end{tabular}

Data are presented as $n(\%)$ or Median (Q1-Q3). $A_{1 C}$ - glycated haemoglobin

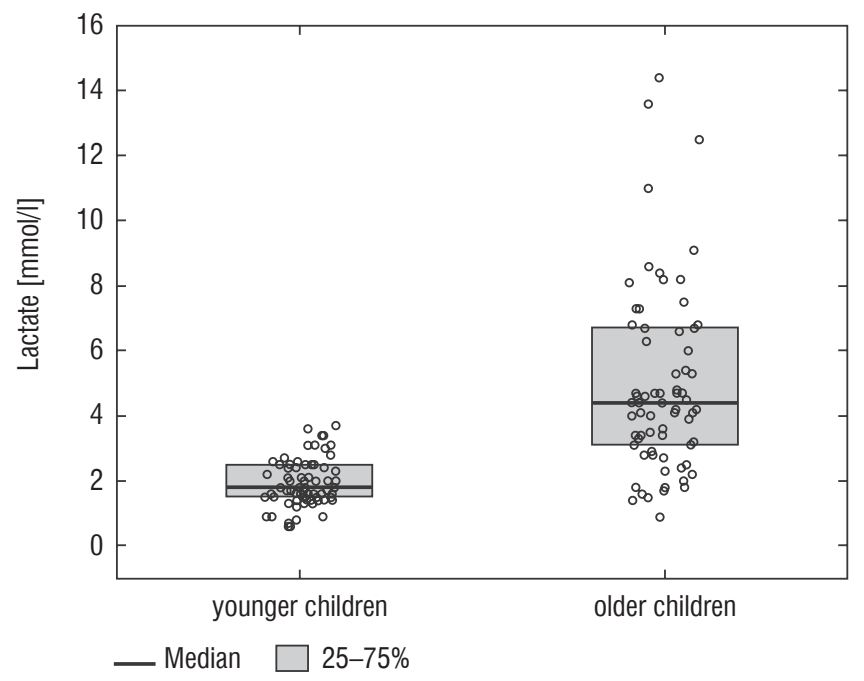

Figure 2. Increase in lactate concentration depending on the age group. The results are shown as a median and IQR sults from 70 of these players: 7 girls (10\%) and 63 boys (90\%), aged 12.0 (11.0-13.7) years. Others were disqualified due to incompleteness of data. Median glycated haemoglobin level $\left(\mathrm{HbA}_{1 \mathrm{c}}\right)$ was 7.3 (7.0-8.2)\%. Sixty-one participants (87\%) used personal insulin pumps, and nine (13\%) used insulin pens. The first age group (10-13 years) comprised 55 players (79\%); the second group (14-17 years) comprised 15 players (21\%). Twenty players (29\%) regularly played football in a sports club. The characteristics of the study group are presented in Table I. The median lactate level prior to matches was $1.8 \mathrm{mmol} / \mathrm{l}$ [1.5-2.5]; it increased to $4.4 \mathrm{mmol} / \mathrm{l}$ [3.1-6.7] after matches $(p<0.001 ;$ Fig. 1). The increase in lactate levels was higher in the older age category $(4.3$ [3.0-10.2] vs. 1.8 [1.0-3.5];

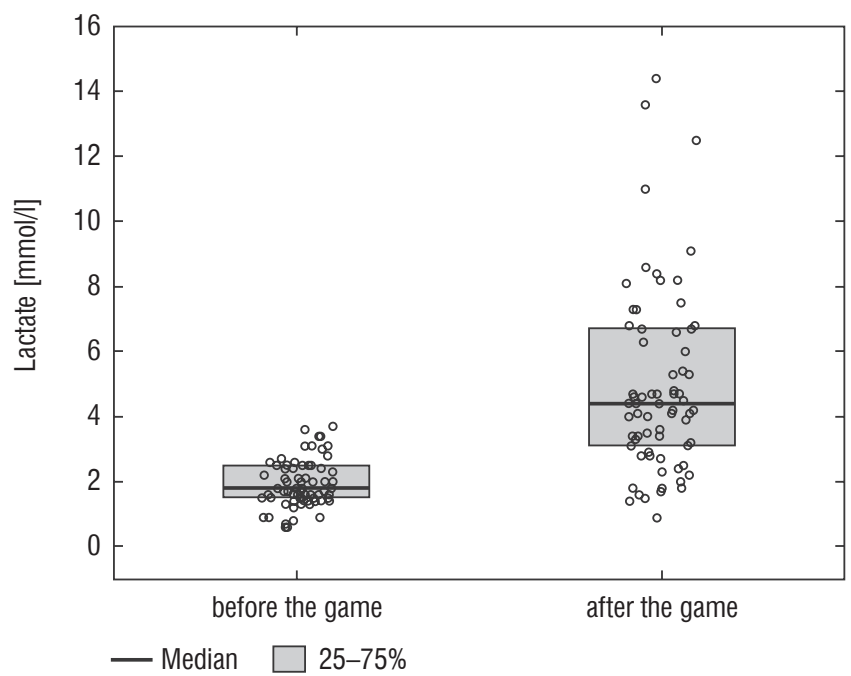

Figure 1. Lactate levels in tournament participants before and after the game. The results are shown as a median and IQR

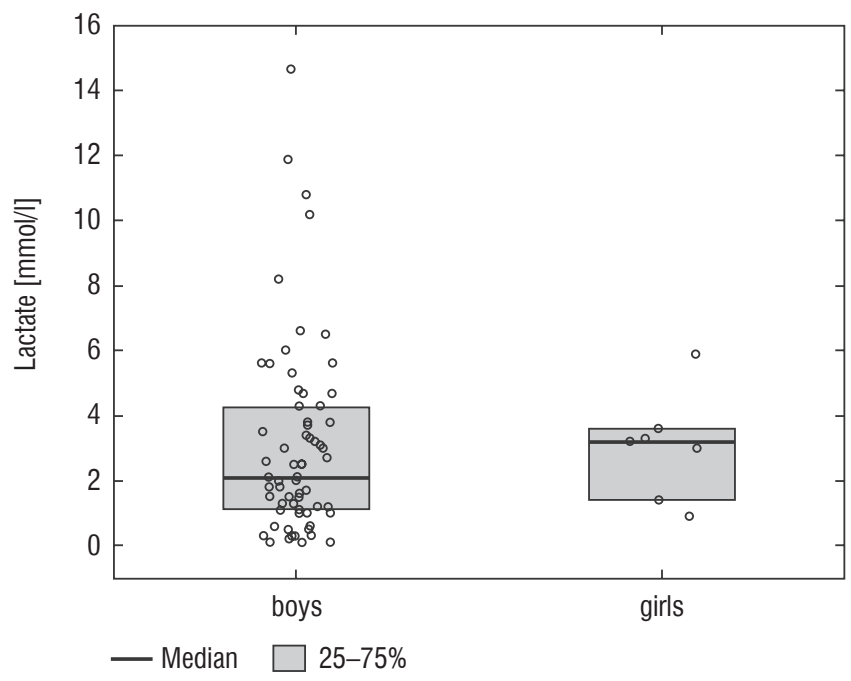

Figure 3. Change in lactate levels depending on gender. The results are shown as a median and IQR 


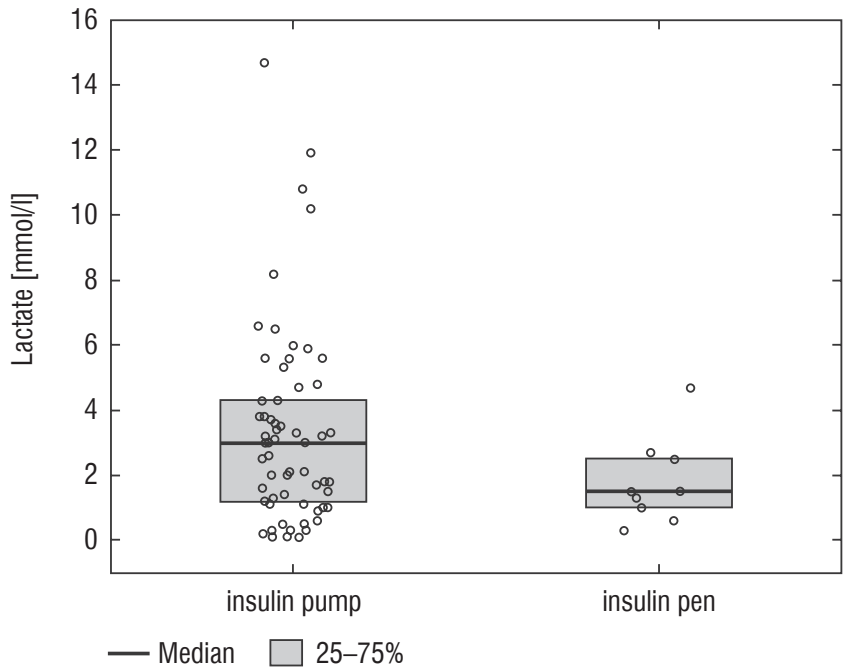

Figure 4. Change in lactate levels depending on the treatment method. The results are shown as a median and IQR

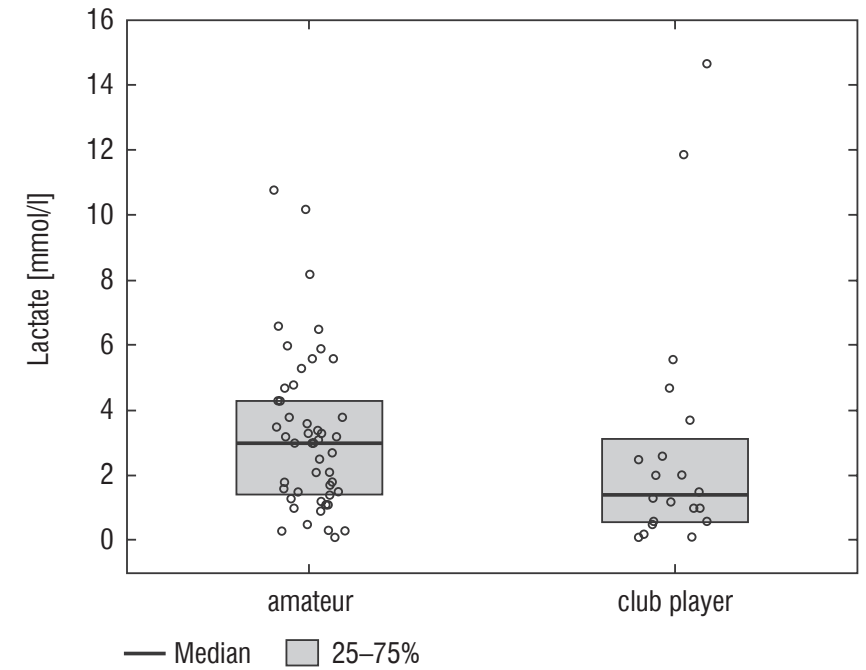

Figure 5. Change in lactate levels depending on participation in a sports club. The results are shown as a median and IQR

Table II. Comparison between children who exceeded OBLA (onset of blood lactate accumulation: $\geq 4$ mmol/l) and those who did not

\begin{tabular}{llll}
\hline Variable & OBLA $<4$ mmol/I $(n=27)$ & OBLA $\geq 4$ mmol/ $(n=43)$ & $p$ \\
\hline Age [years] & $11.4(10.7-12.2)$ & $12.7(11.5-14.2)$ & 0.004 \\
\hline $\mathrm{A}_{1 \mathrm{C}} \%$ & $7.3(7.0-8.2)$ & $7.4(6.9-8.2)$ & 0.975 \\
\hline Sex $\left[\mathrm{M}^{*}\right], n(\%)$ & $25(93)$ & $38(88)$ & 0.699 \\
\hline Insulin pump, $n(\%)$ & $23(85)$ & $38(88)$ & 0.726 \\
\hline Training in a sports club, $n(\%)$ & $11(41)$ & $9(21)$ & 0.076 \\
\hline
\end{tabular}

Data are presented as Median (Q1-Q3) and $n(\%) . \mathrm{A}_{1 \mathrm{C}}$ glycated haemoglobin; $\mathrm{M}^{*}$ male. Statistically significant values are shown in bold.

$p=0.001$; Fig. 2), and was not dependent on gender (3.2 [1.43.6] vs. 2.1 [1.1-4.3], $p=0.597$; Fig. 3) or on use of a personal insulin pump vs insulin pen (3.0 [1.2-4.3] vs. 1.5 [1.0-2.5], $p=0.145$; Fig. 4). The increase in lactate levels also did not differ between players who trained in a sports club and those who played recreationally (1.4 [0.6-3.2] vs. 3.0 [1.4-4.3], $p=0.084$ Fig. 5). A correlation was noted between lactate levels' elevation and children's age: the older the player, the higher the lactate level increase (Rs $=0.253, p=0.034$ ).

Onset of lactate accumulation in the blood, assumed to be a lactate level $\geq 4 \mathrm{mmol} / \mathrm{l}$, was exceeded in $61 \%$ of the tested players. All study participants were divided into two groups depending on the intensity of their metabolic reaction to match exertion load: $<4 \mathrm{mmol} / \mathrm{l}$ or $\geq 4 \mathrm{mmol} / \mathrm{l}$. The study found significant differences in the subjects' age depending on degree of bodily acidification (Table II).

We have proven by univariate logistic regression analysis that age was significantly associated with lactate level $\geq 4 \mathrm{mmol} / \mathrm{l}-$ the older the player, the greater the odds they exceeded the threshold of lactate accumulation in the blood. This correspondence was independent of $\mathrm{HbA}_{1 \mathrm{c}}$, gender, treatment method and training in a sports club vs recreational play (Table III).

\section{Discussion}

People with type 1 diabetes who perform prolonged or intense physical exercise still face the challenge of highly variable blood glucose levels, thus increased risk of hypo- and hyperglycaemia, which may limit their motivation and achievements in sports. Assessing physical activity intensity is a key element in the formulation of recommendations for diabetic athletes. Football is a physical activity of mixed aerobic-anaerobic nature, and the energy exerted by players can differ depending on their age, physical fitness and position played [20]. Blood lactate levels increase together with increased intensity of physical exercise. It should be kept in mind that the increase in lactate level 
Table III. Univariate and multivariate regression analyses

\begin{tabular}{lll}
\hline Variable & OBLA $<4 \mathrm{mmol} / \mathrm{l}(n=27)$ & OBLA $\geq 4 \mathrm{mmol} / \mathrm{l}(n=43)$ \\
\hline Age & $1.45(1.08-1.95) ; 0.006$ & $1.48(1.07-2.03) ; 0.015$ \\
\hline $\mathrm{A}_{1 \mathrm{C}}$ & $1.13(0.69-1.85) ; 0.616$ & $1.05(0.60-1.83) ; 0.865$ \\
\hline Sex & $0.61(0.11-3.38) ; 0.559$ & $1.05(0.16-6.81) ; 0.962$ \\
\hline Insulin pump & $1.01(0.22-4.62) ; 0.991$ & $0.98(0.19-4.910) ; 0.977$ \\
\hline Training in a sports club & $0.39(0.13-1.11) ; 0.076$ & $0.38(0.11-1.23) ; 0.104$ \\
\hline
\end{tabular}

AOR (adjusted odds ratios) ( $\mathrm{Cl}$, confidence intervals) were calculated in a multivariate logistic regression, and the $p$-value was calculated using the Wald test $\left(p<0.05\right.$ was assumed to be significant). The dependent variable was the OBLA $\geq 4$ mmol/l. $A_{1 C}-$ glycated haemoglobin Statistically significant values are shown in bold. *Age was continuous variable.

is not linear, because after the lactate threshold is exceeded, it abruptly rises much more rapidly. A rapid rise in lactate level occurs after ca. $4 \mathrm{mmol} / \mathrm{l}$ (OBLA) is exceeded [21]. In our study, blood lactate level $\geq 4 \mathrm{mmol} / \mathrm{l}$ was exceeded by $61 \%$ of the players, which confirms that during a football match, players with type 1 diabetes perform mixed aerobic-anaerobic exercise. Clearly, intensive anaerobic exercise was a component of most participants' playing style, which indicates a high level of physical activity on the part of the given person. As demonstrated by the GoalDiab Study, the increase in lactates was significantly higher in the older age category. Younger children are metabolically protected from acidification of their bodies through physiological defence mechanisms against the consequences of hypoxia. Similarly to healthy children, children with T1D display high activity by the mitochondrial metabolism enzymes succinate dehydrogenase and citrate synthetase, but lower activity by phosphofructokinase and reduced capacity of lactate to diffuse from the active muscle into the bloodstream [22].

It can be assumed that a person who practices sports regularly, especially in a sports club, has a better level of physical fitness. Regular exercise improves physical fitness and positively influences a number of metabolic processes [23]. An important factor that may influence blood lactate levels is not only players' fitness level, but also their engagement in the given match. A high post-match blood lactate level may result from high motivation to exert effort and perform on the pitch despite symptoms of muscle fatigue [24]. The absence of differences in lactate levels between players who train systematically in football clubs and those who play recreationally indicates similar biochemical reactions in response to match exertion load. It can also be hypothesised that players with a longer history of training ran faster and farther than those with a lower level of aerobic fitness, thus had a delayed reactive surge in their production and release of lactate into the bloodstream.

As demonstrated by Harris et al., healthy adolescents, depending on type and intensity of physical exercise, can have lactate levels considerably exceeding the $4 \mathrm{mmol} / \mathrm{l}$ threshold
[25]. Measuring changes in lactate levels after physical activity also makes it possible to estimate exercise tolerance in children with T1D. Our study found that changes in lactate levels measured before and after matches indicated the ability of children with T1D to engage in intensive physical activity during the football tournament. Their level of physical exertion during the tournament proved to be a safe load for them, as they were able to maintain normal blood glucose levels during and after this activity [17].

The results of the GoalDiab Study also demonstrate that increased lactate levels did not depend on gender. Although girls are less physically active [26], their competitive engagement in sports equals that of boys, which directly impacts the results of their blood lactate measurements. Esbjörnsson-Liljendahl et al. investigated a group of students with the same level of physical fitness performing anaerobic 30 -second sprints. The researchers proved that post-workout lactate levels were $22 \%$ higher in men due to their greater physiological capacity to perform anaerobic exercise [27]. A similar phenomenon was observed by Gratas-Delamarche et al., who confirmed that post-exercise lactate levels were lower in women [28]. This phenomenon can be attributed to the fact that the body weight, especially muscle mass, of the vast majority of males is greater than that of females in comparable age groups [29]. The same association between gender and body weight can be observed in children and adolescents [30]. There have been no adequately designed studies that would demonstrate such differences in the group of children and adolescents.

After the Diabetes Control and Complications Trial (DCTT) was published in 1993, intensive functional insulin therapy (IFIT) became the leading T1D treatment method. This method mimics the physiological circadian rhythm of insulin secretion [31]. Currently, an increasing percentage of patients with T1D are treated with continuous subcutaneous insulin infusion [8]. This method improves blood glucose control and is associated with a lower risk of hypoglycaemia, which translates into a better health-related quality of life [9]. Diabetes treatment using a PIP 
reduces the daily insulin requirement and decreases blood glucose fluctuations compared to treatment based on insulin pens [32]. An interesting finding is that in the case of children's physical activity, PIP therapy does not have a more beneficial effect on blood lactate levels. By contrast, Gawrecki et al. demonstrated that men with T1D who used insulin pens had higher lactate levels directly after a treadmill test than men who used personal insulin pumps [33].Exercise monitoring is a very important issue, especially in metabolic diseases. One of the key parameters assessing exercise intensity and physical fitness is the lactate threshold $[34,35]$. Sport researchers determine the lactate threshold using different methods, to individualise training recommendations for athletes as well as for patients with chronic diseases $[35,36]$. It should be kept in mind that a single set of exercises causes acute metabolic changes in the body in addition to long-term adaptive changes [23]. In patients with type 1 diabetes, aerobic exercise usually causes an abrupt fall in blood glucose level, while anaerobic exercise may cause it to increase, thereby complicating blood glucose control. Mixed aerobic and anaerobic exercise has unpredictable and individual effects in each T1D patient [37]. Very intensive and prolonged exercise may lead to hyperglycaemia. Measuring blood lactate levels is a simple method for assessing the intensity of and engagement in physical activity. Increased lactate levels are associated with an elevated risk of hyperglycaemia.

\section{Limitations}

The study has limitations resulting from its small sample size and the unequal sizes of the groups compared. It would also be worthwhile to assess more factors influencing lactate levels during physical activity than those examined in the study. The correlation between blood lactate levels and glycaemia was not assessed in this paper due to the presence of multiple factors that potentially influenced blood glucose concentrations during the 2-day football tournament. The assessment of glycaemia would also require that the numerous bolus insulin injections be taken into account. The assessment of blood glucose changes in correlation with lactate levels during a football match would require a separate study. Moreover, the study was observational in nature, thus its results need to be verified and compared with a control group. Our results provide the basis for future research projects investigating changes in blood lactate levels in the course of variable-intensity physical exercise, especially in children and adolescents, as well as the benefits resulting from hormonal and metabolic changes that occur during such activity.

\section{Conclusions}

Physical exercise intensity in adolescents with type 1 diabetes during football matches in the course of the football tournament was found to be mixed aerobic-anaerobic exertion. Increases in blood lactate levels after physical exercise were higher in the older subjects and did not depend on gender, method of insulin administration or training in a sports club vs recreational play. The nature of changes in blood lactate levels assessed before and after the matches indicate the ability of adolescents with T1D to engage in high-intensity exercise, similarly to healthy children.

\section{References}

1. Buschur E, Sarma AV, Pietropaolo M, et al. Self-reported autoimmune disease by sex in the diabetes control and complications trial/epidemiology of diabetes interventions and complications (DCCT/EDIC) study. Diabetes Care 2014; 37: e28-e29. doi: 10.2337/dc13-1890.

2. Standards of Medical Care in Diabetes-2017: Summary of Revisions. Diabetes Care 2017; 40 (Suppl 1): S4-S5.

3. Effect of intensive diabetes treatment on the development and progression of long-term complications in adolescents with insulindependent diabetes mellitus: Diabetes Control and Complications Trial. Diabetes Control and Complications Trial Research Group. J Pediatr 1994; 125: 177-188. doi: 10.1016/s0022-3476(94)70190-3.

4. Diabetes Control and Complications Trial Research Group, Nathan DM, Genuth S, et al. The effect of intensive treatment of diabetes on the development and progression of long-term complications in insulin-dependent diabetes mellitus. N Engl J Med 1993; 329: 977-986. doi: 10.1056/NEJM199309303291401.

5. Testa R, Bonfigli AR, Prattichizzo F, et al. The "Metabolic Memory" Theory and the Early Treatment of Hyperglycemia in Prevention of Diabetic Complications. Nutrients 2017; 9: 437. doi: 10.3390/ nu9050437.

6. Cheon CK. Understanding of type 1 diabetes mellitus: what we know and where we go. Korean J Pediatr 2018; 61: 307-314. doi: 10.3345/kjp.2018.06870.

7. Nielsen HB, Ovesen LL, Mortensen LH, et al. Type 1 diabetes, quality of life, occupational status and education level - A comparative population-based study. Diabetes Res Clin Pract 2016; 121: 62-68. doi: 10.1016/j.diabres.2016.08.021.

8. Miculis CP, Mascarenhas LP, Boguszewski MC, Campos Wd. Physical activity in children with type 1 diabetes. J Pediatr (Rio J) 2010; 86: 271-278. doi: 10.2223/JPED.2003.

9. Venkatasamy W, Pericherla S, Manthuruthil S, et al. Effect of Physical activity on Insulin Resistance, Inflammation and Oxidative Stress in Diabetes Mellitus. J Clin Diagn Res 2013; 7: 1764-1766. doi: 10.7860/JCDR/2013/6518.3306.

10. PTD, Guidelines on the management of diabetic patients. A position of Diabetes Poland. Clinical Diabetology 2020.

11. Lukács A, Barkai L. Effect of aerobic and anaerobic exercises on glycemic control in type 1 diabetic youths. World J Diabetes 2015; 6: 534-542. doi: 10.4239/wjd.v6.i3.534.

12. Juel C, Halestrap AP. Lactate transport in skeletal muscle - role and regulation of the monocarboxylate transporter. J Physiol 1999; 517 (Pt 3): 633-642. doi: 10.1111/j.1469-7793.1999.0633s.x. 
13. Proia P, Di Liegro CM, Schiera G, et al. Lactate as a Metabolite and a Regulator in the Central Nervous System. Int J Mol Sci 2016; 17: 1450. doi: 10.3390/ijms17091450.

14. Bangsbo J, Hostrup M. Lactate production contributes to development of fatigue during intense exercise in humans. Ugeskr Laeger 2019; 181 (8).

15. Andrzejewski M, et al. Influence of speed training loads on the activity of creatine kinase and lactic dehydrogenase and the concentration of oxypurines in blood samples of young football players. Medycyna Sportowa 2008; 24: 149-158.

16. Bangsbo J. Fitness training in football: a scientific approach. August Krogh Institute, University of Copenhagen, Denmark 1994.

17. Gawrecki A, Araszkiewicz A, Szadkowska A, et al. Assessment of Safety and Glycemic Control During Football Tournament in Children and Adolescents With Type 1 Diabetes-Results of GoalDiab Study. Pediatr Exerc Sci 2019; 31: 401-407. doi: 10.1123/pes.2018-0264.

18. Mayer-Davis EJ, Kahkoska AR, Jefferies C, et al. ISPAD Clinical Practice Consensus Guidelines 2018: Definition, epidemiology, and classification of diabetes in children and adolescents. Pediatr Diabetes. 2018; 19 Suppl 27 (Suppl 27): 7-19. doi: 10.1111/pedi.12773

19. Piya-Amornphan N, Santiworakul A, Cetthakrikul S, Srirug P. Physical activity and creativity of children and youths. BMC Pediatr 2020; 20: 118. doi: 10.1186/s12887-020-2017-2

20. Buchheit M, Mendez-Villanueva A, Simpson BM, Bourdon PC. Match running performance and fitness in youth soccer. Int J Sports Med 2010; 31: 818-825. doi: 10.1055/s-0030-1262838

21. Billat $V L$, Sirvent $P, P y G$, et al. The concept of maximal lactate steady state: a bridge between biochemistry, physiology and sport science. Sports Med 2003; 33: 407-426. doi: 10.2165/00007256200333060-00003.

22. Zwiren LD. Anaerobic and aerobic capacities of children. Pediatric Exercise Science 1989; 1: 31-44.

23. Moghetti P, Bacchi E, Brangani C, et al. Metabolic Effects of Exercise. Front Horm Res 2016; 47: 44-57. doi: 10.1159/000445156.

24. Ciepielowski T, Pilch W, Ambroży T. Zmiany stężenia mleczanu podczas typowego treningu pływackiego młodych zawodniczek. Medicina Sportiva Practica 2010; 11: 70-75.

25. Harris NK, Dulson DK, Logan GRM, et al. Acute Responses to Resistance and High-Intensity Interval Training in Early Adolescents. J Strength Cond Res 2017; 31: 1177-1186. doi:10.1519/ JSC. 0000000000001590.

26. Taverno Ross SE, Dowda M, Beets MW, Pate RR. Physical activity behavior and related characteristics of highly active eighth-grade girls. J Adolesc Health 2013; 52: 745-751. doi: 10.1016/j.jadohealth.2012.12.003.

27. Esbjörnsson-Liljedahl M, Sundberg CJ, Norman B, Jansson E. Metabolic response in type I and type II muscle fibers during a 30-s cycle sprint in men and women. J Appl Physiol (1985) 1999; 87: 1326-1332. doi: 10.1152/jappl.1999.87.4.1326.

28. Gratas-Delamarche A, Le Cam R, Delamarche P, et al. Lactate and catecholamine responses in male and female sprinters during a Wingate test. Eur J Appl Physiol Occup Physiol 1994; 68: 362-366. doi: 10.1007/BF00571458.

29. Kułaga Z, Palczewska I. Siatki centylowe wysokości, masy ciała i wskaźnika masy ciała dzieci i młodzieży w Polsce - wyniki badania OLAF. 2010.

30. Burdukiewicz A, Andrzejewska J, Pietraszewska J, et al. Skład ciała młodzieży w okresie pokwitania badany metodą bioelektrycznej impedancji. Acta Bio-Optica et Informatica Medica. Inżynieria Biomedyczna 2012; 18: 15-19.

31. Duron F. Intensive insulin therapy in insulin-dependent diabetes mellitus, the results of the diabetes control and complications trial. Biomed Pharmacother 1995; 49: 278-282. doi: 10.1016/07533322(96)82643-6

32. Lepore G, Dodesini AR, Nosari I, Trevisan R. Effect of continuous subcutaneous insulin infusion vs multiple daily insulin injection with glargine as basal insulin: an open parallel long-term study. Diabetes Nutr Metab 2004; 17: 84-89.

33. Gawrecki A, Naskret D, Niedzwiecki P, et al. High-intensity Exercise in Men with Type 1 Diabetes and Mode of Insulin Therapy. Int J Sports Med 2017; 38: 329-335. doi: 10.1055/s-0042-123046.

34. Jones $A M$, Carter $H$. The effect of endurance training on parameters of aerobic fitness. Sports Med 2000; 29: 373-386. doi: 10.2165/00007256-200029060-00001.

35. Faude O, Kindermann W, Meyer T. Lactate threshold concepts: how valid are they? Sports Med 2009; 39: 469-490. doi: 10.2165/00007256-200939060-00003.

36. Yang WH, Park H, Grau M, Heine O. Decreased Blood Glucose and Lactate: Is a Useful Indicator of Recovery Ability in Athletes?. Int J Environ Res Public Health 2020; 17: 54-70. doi: 10.3390/ ijerph17155470.

37. Miller BF, Fattor JA, Jacobs KA, et al. Lactate and glucose interactions during rest and exercise in men: effect of exogenous lactate infusion. J Physiol 2002; 544: 963-975. doi: 10.1113/jphysiol.2002.027128. 